\title{
ПОВТОРНІ ВИПАДКИ ІНФІКУВАННЯ SARS-COV-2
}

\author{
${ }^{1}$ Харківська медична академія післядипломної освіти, \\ ${ }^{2}$ Тернопільський національний медичний університет імені І.Я. Горбачевського
}

Обговорюється проблема повторного інфрікування SARS-CoV-2. Довести випадок реінфекції не просто, адже для цього потрібно не тільки отримати два позитивні ПЛР-тести до SARS-CoV-2 при двох випадках захворювання, а й довести, що в обох випадках це «живі» та різні шттами вірусу.

Основними причинами розвитку реінсрекції SARSCoV-2 є стан імунної системи на період повторного контакту зі збудником, тобто наявність імунодефріциту, а також кількість вірусу, що попав в організм людини в цей період. Це може бути пов'язано з надзвичайно високим рівнем вірусного навантаження новим штамом, який спричинив сильнішу реакцію макроорганізму, або більш вірулентним штамом вірусу.

Повторно інфріковані SARS-CoV-2, як правило, переносять хворобу тяжче і майже завжди з пневмонією.

Можливість повторного і, навіть, багаторазового інфрікування створює ситуацію постійної циркуляції SARS-CoV-2 з багаторічною проблемою ліквідації цієі інфрекції взагалі (нові мутації, нові вакцини тощо).

Ключові слова: SARS-CoV-2, повторне інфрікування, імунна відповідь, COVID-19, френомен антитілозалежного посилення інфекції.

Одна з найважливіших проблем в галузі громадського здоров'я, що зараз активно обговорюється, - це захисна імунна відповідь після перенесеної COVID-19 і можливість повторного інфрікування. Можливість повторного зараження взагалі не розглядалася і всерйоз не сприймалася, оскільки у пацієнтів, які одужали від COVID-19, відбувалася сероконверсія антитіл до SARSCoV-2. У зв'язку з цим багато урядів і організацій громадського здоров'я навіть пропонували ідею «паспорта імунітету» 3 метою відновлення соціальних та економічних норм суспільства. Разом з тим низка клінічних досліджень виявила невисокі титри відповідних антитіл, або швидке їх падіння у реконвалесцентів, чи взагалі їх відсутність [1, 2]. Водночас ряд повідомлень, незалежно одне від одного, представили докази повторного іноікування SARS-CoV-2 після одужання, що розцінювалося на той час як рецидив інорекції $[3,4]$. При цьому
ПлР-дослідження засвідчили зникнення вірусу між позитивними їх результатами протягом двох періодів інфрікування. Крім того, майже у всіх пацієнтів результати секвенування вірусного геному безсумнівно показали інорікування окремим штамом вірусу у другому епізоді, який не був широко розповсюджений до періоду вторинної інорекції, що й виключає можливість рецидиву первинної інфекції. Більш того, у частини пацієнтів розвинулась імунна відповідь у межах діапазону, який міг би вважатися захисним, але при цьому вони були повторно іноріковані. Зазначене, ймовірно, безпосередньо стосується й ефективності вакцин. Тому такі пацієнти 3 нейтралізувальними антитілами в реконвалесцентний період не повинні вважатися убезпеченими від повторного інфрікування.

Повторно інфріковані SARS-CoV-2, як правило, переносять хворобу тяжче і майже завжди з пневмонією.

Наявність повторного зараження SARS-CoV-2, а не рецидиву, засвідчили дослідження геномів виділених вірусів. У випадку, коли між першим і другим виділеними штамами вдалося виявити помітні розбіжності у вірусних геномах, мова йде про вірогідність повторного інфрікування. Водночас деякі фрахівці вважають, що наявність мутованих штамів у зазначеній ситуації не є домінуючим критерієм визначення повторного випадку COVID-19, а цим критерієм повинен бути один і той же штам SARSCoV-2 і тому, на їхню думку, мова може йти лише про поодинокі випадки повторного інфікування у світі $[5,6]$. Але при цьому необхідно думати і про те, що у деяких випадках може скластися така ситуація, коли після одужання від COVID-19 людина інфрікувалася іншим вірусом (навіть через декілька діб) з розвитком симптомів ГРЗ і якщо в цей час ще виділятимуться «уламки» SARS-CoV-2, може скластися помилкове уявлення про повторне зараження. Тому, щоб довести реальний випадок реінфекції, потрібно не тільки отримати два позитивні ПЛР-тести до SARS-CoV-2 при двох випадках захворювання, а й довести, що в обох випадках це «живі» та різні штами вірусу.

Накопичення наукового матеріалу натепер показало, що основними причинами розвитку реінфекції SARS- 
CoV-2 є стан імунної системи на період повторного контакту зі збудником, тобто наявність імунодефріциту, а також кількість вірусу, що попав в організм людини в цей період. Це може бути пов'язано з надзвичайно високим рівнем вірусного навантаження новим штамом, який спричинив сильнішу реакцію макроорганізму (враховуючи те, що маніфестні форми COVID-19 проявляються агресивніше), або більш вірулентною версією вірусу. При цьому повторне зараження може відбуватися через легкий перебіг первинної інфекції, при якій практично не сорормувалась імунна відповідь, або імунна система була скомпрометована іншими захворюваннями і ситуаціями, що склалися. За таких обставин антитіла, якщо і з'являлися, то були недовготривалими.

Високий рівень антитіл, як з'ясувалося, зовсім не гарантує 100 \% захисту від реінфрікування SARS-CoV-2. Це можливо лише в тому випадку, коли організм ослаблений, наприклад через тяжкі хронічні захворювання і вірус знаходить «пролом», незважаючи на наявність цих антитіл і клітинного імунітету.

Попри те, що в крові перехворілих виявляються антиковідні антитіла, не всі вони володіють однаковими протективними властивостями. У цьому плані перевагу віддають нейтралізувальним імуноглобулінам, які прикріплюються до збудника, позбавляючи його можливості уражати нові таргетні клітини. Дослідження показують, що у 30 \% пацієнтів рівень таких антитіл був украй низьким. Тому у звільненні організму від SARS-CoV-2 ВООЗ віддає перевагу клітинному імунітету. Клітинний імунітет може утримуватися набагато довше, ніж гуморальний, але, на жаль, ми ще не можемо точно його вимірювати.

Стійкі нейтралізувальні антитіла до SARS-CoV-2 залишаються відносно стабільними протягом декількох місяців після інфрікування. Повідомляється, що після першого інсрікування антитіла починають зникати після 5 міс. і ризик повторного інорікування залишається $[7,8]$. Разом 3 тим, мутований штам при попаданні в організм перехворілого може діяти дещо по іншому. Зокрема, виявлена здатність нових штамів SARS-CoV-2 ухилятися від впливу антитіл. Логічно припустити, і це очевидно, що навіть вакцинація не завжди зможе захистити від інфрікування (хоча може знизити ступінь тяжкості хвороби). Дослідження вчених клініки Оксорордського університету показали [9], що:

- пік формування антиковідних антитіл припадає на 24-у добу першого позитивного результату ПЛР-тесту,

- в подальшому їх рівень починає знижуватися і до 85 діб після інфрікування вони знижуються приблизно на половину,

- зберігаються антитіла в організмі 137 діб від пікового значення, а потім остаточно зникають.
В іншому дослідженні [10] було встановлено, що майже у всіх піддослідних антитіла до SARS-CoV-2 зберігаються протягом 94 діб (період спостереження). У Китаї було доведено, що через 2 міс. рівень імуноглобулінів у крові людей, які перенесли COVID-19 безсимптомно, був близьким до нуля $[11,12]$.

Але ризик повторного інфікування зумовлюється не тільки величиною і тривалістю специфічного імунітету кожної окремої людини, але й різними обставинами зараження.

У тих хворих, в яких COVID-19 повторно перебігає тяжко, відзначають підвищення температури тіла, біль голови, кашель, нудоту та кишкові розлади, повторну втрату нюху і смаку. Повторні випадки хвороби нерідко сприймаються як звичайна простуда. Навіть якщо при цьому зникли нюх і смак, то це розцінюється як залишкові явища після перенесеної хвороби.

При повторному інфрікуванні може статися антитілозалежне посилення інфекції (Antibody-DependentEnhancement, ADE) - механізм, за допомогою якого віруси використовують імунну систему для ефективнішого і масовішого ураження організму [13]. Це явище вчені вже фріксували при недузі, зумовленій бета-штамом SARS-CoV-2, та інших захворюваннях, таких як гарячка Денге. Також можлива ситуація, коли при високому вмісті антитіл у крові й достатньому клітинному імунітеті у випадку ослаблення організму відбувається повторне інфрікування. При високому титрі антитіл повторний перебіг COVID-19 очікувано мав би бути значно легшим, при низькому - тяжчим. Але на даний момент вчені ще не визначалися з достовірним рівнем антитіл, необхідним для блокування повторного інфікування [14]. У той же час слід враховувати динаміку титрів антитіл. Вакцина, як зазначалося, також не є панацеєю від загрози повторної COVID-19.

Частота повторного інфрікування SARS-CoV-2 тільки вивчається, вона може бути орієнтовно встановлена лише при цілеспрямованому дослідженні. Стало відомо, що перебіг хвороби може бути маніфестним або безсимптомним. Так, в одному із організованих колективів (військовослужбовці у кількості майже 2,5 тис. осіб) $10 \%$ особового складу захворіли на COVID-19 вдруге. Всі випадки хвороби перебігали безсимптомно. Причому вірусне навантаження в 10 разів було меншим, ніж на первинному її етапі. При вивченні імунної відповіді в учасників експерименту нейтралізувальні антитіла, що блокують вірус при попаданні в організм, були виявлені у 31,6 \% обстежених, які заразилися повторно [15]. Зазначене свідчить про те, що причиною реінсрекції була слабкість імунної відповіді після первинної інфекції.

Повторний підтверджений випадок COVID-19 у Гонконзі також перебігав безсимптомно [16] і з недостатнім 
гуморальним захистом від SARS-CoV-2. Випадок підтверджений секвенуванням геному вірусу, що довело інфікування іншим штамом збудника. Перше інфікування SARS-CoV-2 спричинило легкий перебіг хвороби 3 відсутністю антитіл. Вони з'явилися лише на 5-у добу повторного інорікування, після чого концентрація РНК SARS-CoV-2 досить швидко впала.

Не виключено, що в деяких людей повторна дія вірусу може викликати й серйозні наслідки. Невідомо, скільки атак у природних умовах потрібно імунній системі, щоб вона забезпечила тривалу захисну дію від SARS-CoV-2. Тому післявакцинний імунітет повинен бути достатньо напруженим, демонструючи таку ж ефективність, як і природний. Як показала практика, потрібні повторні ін'єкції вакцини. А це може втратити надію на форомвання тривалого колективного імунітету.

Згідно з Наказом МОЗ України, повторне захворювання COVID-19 реєструється у разі позитивного результату дослідження методом ПЛР або швидкими тестами на визначення SARS-CoV-2 та/або тесту на антигени SARS-CoV-2 методом IФA, отриманими повторно, але не менше ніж через 60 діб після первинного позитивного результату дослідження, у разі, якщо нові симптоми COVID-19 виникли після періоду повного одужання першого епізоду захворювання [17].

Центр контролю і профрілактики захворювань CDC у США інформує, що позитивний результат мазка на SARS-CoV-2 протягом 90 діб після первинного інфікування скоріше свідчить про стійке виділення вірусу, ніж про повторне інорікування. Водночас відзначається, що позитивний результат тестування PHK SARS-CoV-2 не обов'язково вказує на постійне виділення вірусу протягом зазначеного періоду [18].

\section{Література}

1. Antibody responses to SARS-CoV-2 in patients with COVID-19 / Q. X. Long, B. Z. Liu, H. J. Deng [et al.] // Nature Medicine. - 2020. - Vol. 26, N 6. - P. 845-848.

2. Rapid decay of anti-SARS-CoV-2 antibodies in persons with mild Covid-19 / F. J. Ibarrondo, J. A. Fulcher, D. Goodman-Meza [et al.] // The New England Journal of Medicine. - 2020. - N 383. P. 1085-1087.

3. Recurrence of positive SARS-CoV-2 RNA in COVID-19: A case report / D. Chen, W. Xu, Z. Lei [et al.] // International Journal of Infectious Diseases. - 2020. - N 93. - P. 297-299.

4. Is novel coronavirus 2019 reinfection possible? Interpreting dynamic SARS-CoV-2 test results / N. M. Duggan, M. L. Stephanie,
B країнах ЄC інтервал між епізодами COVID-19 становить від 45 до 90 діб (доказ виявлення антигенів - ПЛР, швидкий антигенний тест, сиквенс). У США зафріксований випадок повторного інфікування SARSCoV-2, коли упродовж 1,5 міс. чоловік перехворів двічі, що було підтверджено виділенням двох різних штамів вірусу [19].

Отже $є$ група ризику повторного зараження з розвитком інсрекційного процесу. У ній перебувають особи із серйозними порушеннями імунної системи (зокрема ті, що застосовують імуносупресори), пацієнти з онкологічними та автоімунними недугами, ендокринними порушеннями тощо. Але пояснити цю ситуацію тільки титрами антитіл не зовсім коректно, хоча фахівці ВООЗ підтримують цю версію. Можливість повторного і, навіть, багаторазового інфрікування створює ситуацію постійної циркуляції SARS-CoV-2 з багаторічною проблемою ліквідації цієї інфекції взагалі (нові мутації, нові вакцини тощо) [20].

До вікової групи підвищеного ризику повторного зараження SARS-CoV-2 входять переважно люди старше 65 років. Експерти оцінили рівень їх захисту від повторного зараження у 47 \%. Тому отримані дані підтверджують стратегію надання пріоритету під час вакцинації людям похилого віку [21].

У людей старше 75 років концентрація антиковідних антитіл зменшується значно швидше, ніж у молодих. Крім того, рівень антитіл залежить від ступеня тяжкості перенесеної хвороби, що й відображається на ризику повторного інфікування. Викликає зацікавлення повідомлення про те, що у медичних працівників, які перехворіли на COVID-19, концентрація антитіл знижується повільніше. Згідно з версією, це може бути пов'язано 3 постійним професійним реінфікуванням та отриманням значної дози вірусу на момент зараження [22-24].

B. C. Shannon [et al.] // American Journal of Emergency Medicine. 2020. - N 39. - P. 256.e1-256.e3.

5. Kim A. Y. Re-infection with SARS-CoV-2: what goes around may come back around / A. Y. Kim, R. T. Gandhi // Clinical Infectious Diseases: An Official Publication of the Infectious Diseases Society of America. - 2020.

6. Understanding the implications of SARS-CoV-2 re-infections on immune response milieu, laboratory tests and control measures against COVID-19 / J. O. Mustapha, I. N. Abdullahi, O. O. Ajagbe [et al.] // Heliyon. - 2021. - P. e05951.

7. Robust neutralizing antibodies to SARS-CoV-2 infection persist for months / A. Wajnberg, F. Amanat, A. Firpo [et al.] // Science. - 2020. - N 370. - P. 1227-1330. 


\section{ОГЛЯДИ ТА ЛЕКЦІї}

8. Antibody responses 8 months after asymptomatic or mild SARS-CoV-2 infection / P. G. Choe, K. H. Kim, C. K. Kang [et al.] // Emerging Infectious Diseases. - 2021. - Vol. 27, N 3. - P. 928

9. The duration, dynamics, and determinants of severe acute respiratory syndrome Coronavirus 2 (SARS-CoV-2) antibody responses in individual healthcare workers / S. F. Lumley, J. Wei, D. O'Donnell [et al.] // Clinical Infectious Diseases. - 2021.

10. Longitudinal observation and decline of neutralizing antibody responses in the three months following SARS-CoV-2 infection in humans / J. Seow, C. Graham, B. Merrick [et al.] // Nature microbiology. - 2020. - Vol. 5, N 12. - P. 1598-1607.

11. Seroprevalence and humoral immune durability of antiSARS-CoV-2 antibodies in Wuhan, China: A longitudinal, populationlevel, cross-sectional study / Z. He, L. Ren, J. Yang [et al.] // The Lancet. - 2021. - Vol. 397, N 10279. - P. 1075-1084.

12. Viral and antibody kinetics of COVID-19 patients with different disease severities in acute and convalescent phases: a 6-month follow-up study / Z. He, L. Ren, J. Yang [et al.] // Virologica Sinica. - 2020. - Vol. 35, N 6. - P. 820-829.

13. Супотницкий М.В. Неугодная иммунология / М.В. Супотницкий // Актуальная инфектология. - 2016. - № 2(11). - С. 73-97.

14. COVID-19 reinfection in the presence of neutralizing antibodies / J. Zhang, N. Ding, L. Ren [et al.] // National science review. - 2021. - Vol. 8, iss. 4. - nwab006. -

15. SARS-CoV-2 transmission among marine recruits during quarantine / A. G. Letizia, I. Ramos, A. Obla [et al.] // New England Journal of Medicine. - 2020. - Vol. 383, N 25. - P. 2407-2416.

16. COVID-19 re-infection by a phylogenetically distinct SARScoronavirus- 2 strain confirmed by whole genome sequencing / K. K. To,
I. F. Hung, J. D. Ip [et al.] // Clinical Infectious Diseases: An Officia Publication of the Infectious Diseases Society of America. - 2020.

17. Наказ МОЗ України від 30.05.2021 № 1056 «Про затвердження Змін до Стандартів медичної допомоги «Коронавірусна хвороба (COVID-19)»»»,

18. Interim Guidance on Ending Isolation and Precuations for Adults with COVID-19 / Centers for Disease Control and Prevention // US Department of Health \& Human Services, Centers for Disease Control and Prevention. Retrieved May. - 2021. - Vol. 16.

19. Genomic evidence for reinfection with SARS-CoV-2: A case study / R. L. Tillett, J. R. Sevinsky, P. D. Hartley [et al.] // The Lancet Infectious Diseases. - 2021. - Vol. 21, N 1. - P. 52-58.

20. Antibody persistence in the first 6 months following SARSCoV-2 infection among hospital workers: a prospective longitudinal study / A. G. L'Huillier, B. Meyer, D. O. Andrey [et al.] // Clinical Microbiology and Infection. - 2021. - Vol. 27, N 5. - P. 784-e1.

21. SARS-CoV-2 infection in properly vaccinated healthcare workers / M. H. Porto, B. Castro, Z. Diaz [et al.] // International Journal of Infectious Diseases. - 2021.

22. SARS-CoV-2 reinfection: A case series from a 12-month longitudinal occupational cohort / C. D. Mack, C. Tai, R. Sikka [et al.] // Clinical Infectious Diseases. - 2021.

23. High SARS-CoV-2 antibody prevalence among healthcare workers exposed to COVID-19 patients / Y. Chen, X. Tong, J. Wang [et al.] // Journal of Infection. - 2020. - Vol. 81, N 3. - P. 420-426.

24. SARS-CoV-2 exposure, symptoms and seroprevalence in healthcare workers in Sweden / A.S. Rudberg, S. Havervall, A. Månberg [et al.] // Nature Communications. - 2020. - Vol. 11, N 1. - P. 1-8.

\section{References}

1. Long, Q.X., Liu, B.Z., Deng, H.J., Wu, G.C., Deng, K., Chen, Y.K., ... \& Huang, A.L. (2020). Antibody responses to SARSCoV-2 in patients with COVID-19. Nature Medicine, 26 (6), 845-848.

2. Ibarrondo, F.J., Fulcher, J.A., Goodman-Meza, D., Elliott, J., Hofmann, C., Hausner, M.A., ... \& Yang, O.O. (2020). Rapid decay of anti-SARS-CoV-2 antibodies in persons with mild Covid-19. New England Journal of Medicine, 383 (11), 1085-1087.

3. Chen, D., Xu, W., Lei, Z., Huang, Z., Liu, J., Gao, Z., \& Peng, L. (2020). Recurrence of positive SARS-CoV-2 RNA in COVID-19: a case report. International Journal of Infectious Diseases, 93, 297-299.

4. Duggan, N.M., Ludy, S.M., Shannon, B.C., Reisner, A.T., \& Wilcox, S.R. (2021). Is novel coronavirus 2019 reinfection possible? Interpreting dynamic SARS-CoV-2 test results. The American Journal of Emergency Medicine, 39, 256-e1.

5. Kim, A.Y., \& Gandhi, R.T. (2020). Re-infection with SARSCoV-2: what goes around may come back around. Clinical Infectious Diseases: An Official Publication of the Infectious Diseases Society of America.

6. Mustapha, J.O., Abdullahi, I.N., Ajagbe, O.O., Emeribe, A.U., Fasogbon, S.A., Onoja, S.O., ... \& Oyewusi, S. (2021). Understanding the implications of SARS-CoV-2 re-infections on immune response milieu, laboratory tests and control measures against COVID-19. Heliyon, e05951.

7. Wajnberg, A., Amanat, F., Firpo, A., Altman, D.R., Bailey, M.J., Mansour, M., ... \& Cordon-Cardo, C. (2020). Robust

neutralizing antibodies to SARS-CoV-2 infection persist for months. Science, 370 (6521), 1227-1230.

8. Choe, P.G., Kim, K.H., Kang, C.K., Suh, H.J., Kang, E., Lee, S.Y., ... \& Oh, M.D. (2021). Antibody responses 8 months after asymptomatic or mild SARS-CoV-2 infection. Emerging Infectious Diseases, 27 (3), 928

9. Lumley, S.F., Wei, J., O'Donnell, D., Stoesser, N.E., Matthews, P.C., Howarth, A., ... \& Fowler, P.W. (2021). The duration, dynamics, and determinants of severe acute respiratory syndrome Coronavirus 2 (SARS-CoV-2) antibody responses in individual healthcare workers. Clinical Infectious Diseases.

10. Seow, J., Graham, C., Merrick, B., Acors, S., Pickering, S., Steel, K. J., ... \& Doores, K. J. (2020). Longitudinal observation and decline of neutralizing antibody responses in the three months following SARS-CoV-2 infection in humans. Nature Microbiology, 5 (12), 15981607.

11. He, Z., Ren, L., Yang, J., Guo, L., Feng, L., Ma, C., ... \& Wang, C. (2021). Seroprevalence and humoral immune durability of anti-SARS-CoV-2 antibodies in Wuhan, China: a longitudinal, population-level, cross-sectional study. The Lancet, 397 (10279), 1075-1084.

12. Zhang, X., Lu, S., Li, H., Wang, Y., Lu, Z., Liu, Z., ... \& Hou, J. (2020). Viral and antibody kinetics of COVID-19 patients with different disease severities in acute and convalescent phases: a 6-month followup study. Virologica Sinica, 35 (6), 820-829.

13. Supotnitskiy, M.V. (2016). Undesirable immunology. Aktualnaya infektologiya - Actual Infectology, 2 (11), $73-97$ [in Russian]. 
14. Zhang, J., Ding, N., Ren, L., Song, R., Chen, D., Zhao, X., ... \& Zeng, H. (2021). COVID-19 reinfection in the presence of neutralizing antibodies. National Science Review, 8(4), nwab006.

15. Letizia, A.G., Ramos, I., Obla, A., Goforth, C., Weir, D.L., Ge, Y., ... \& Sealfon, S.C. (2020). SARS-CoV-2 transmission among marine recruits during quarantine. New England Journal of Medicine, 383 (25), 2407-2416.

16. To, K.K., Hung, I.F., Ip, J.D., Chu, A.W., Chan, W.M. Tam, A.R., ... \& Yuen, K.Y. (2020). COVID-19 re-infection by a phylogenetically distinct SARS-coronavirus-2 strain confirmed by whole genome sequencing. Clinical Infectious Diseases: An Official Publication of the Infectious Diseases Society of America.

17. Order of the Ministry of Health of Ukraine dated 30.05.2021 N 1056 «On approval of Amendments to the Standards of medical care «Coronavirus disease (COVID-19)».

18. Centers for Disease Control and Prevention. (2021). Interim Guidance on Ending Isolation and Precuations for Adults with COVID-19. US Department of Health \& Human Services, Centers for Disease Control and Preventio.

19. Tillett, R.L., Sevinsky, J.R., Hartley, P.D., Kerwin, H., Crawford, N., Gorzalski, A., ... \& Pandori, M. (2021). Genomic evidence

\section{REPEATED CASES OF SARS-COV-2 INFECTION}

V.P. Maly ${ }^{1}$, V.S. Kopcha ${ }^{2}$

${ }^{1}$ Kharkiv Medical Academy of Postgraduate Education,

${ }^{2}$ I. Horbachevsky Ternopil National Medical University

SUMMARY. The problem of re-infection with SARSCoV-2 is discussed. It is not easy to prove the case of reinfection, because it requires not only to obtain two positive PCR tests for SARS-CoV-2 in two cases, but also to prove that in both cases they are "live" and different strains of the virus.

The main reasons for the development of SARS-CoV-2 reinfection are the state of the immune system during the period of repeated contact with the pathogen, ie the presence of immunodeficiency, as well as the amount of virus that entered the human body during this period. This may be due to the extremely high viral load of the new strain, which caused a stronger reaction of the microorganism, or a more virulent strain of the virus.

Re-infected SARS-CoV-2 tends to carry the disease more severely and almost always with pneumonia.

The possibility of repeated and even repeated infection creates a situation of constant circulation of SARS-CoV-2 with a long-standing problem of elimination of this infection in general (new mutations, new vaccines, etc.).

Key words: SARS-CoV-2; re-infection; immune response; COVID-19; antibody-dependent-enhancement. for reinfection with SARS-CoV-2: a case study. The Lancet Infectious Diseases, 21 (1), 52-58.

20. L'Huillier, A.G., Meyer, B., Andrey, D.O., Arm-Vernez, I., Baggio, S., Didierlaurent, A., ... \& Kaiser, L. (2021). Antibody persistence in the first 6 months following SARS-CoV-2 infection among hospital workers: a prospective longitudinal study. Clinical Microbiology and Infection, 27 (5), 784-e1.

21. Porto, M.H., Castro, B., Diaz, Z., Pedroso, Y., Ramos, M.J., \& Lecuona, M. (2021). SARS-CoV-2 infection in properly vaccinated healthcare workers. International Journal of Infectious Diseases.

22. Mack, C.D., Tai, C., Sikka, R., Grad, Y.H., Maragakis, L.L., Grubaugh, N.D., ... \& DiFiori, J. (2021). SARS-CoV-2 reinfection: A case series from a 12-month longitudinal Occupational Cohort. Clinical Infectious Diseases.

23. Chen, Y., Tong, X., Wang, J., Huang, W., Yin, S., Huang, R., ... \& Wu, C. (2020). High SARS-CoV-2 antibody prevalence among healthcare workers exposed to COVID-19 patients. Journal of Infection, 81 (3), 420-426.

24. Rudberg, A.S., Havervall, S., Månberg, A., Falk, A.J., Aguilera, K., Ng, H., ... \& Thålin, C. (2020). SARS-CoV-2 exposure, symptoms and seroprevalence in healthcare workers in Sweden. Nature Communications, 11 (1), 1-8.

\section{Відомості про авторів:}

Малий Василь Пантелейович - д. мед. н., професор, завідувач кафедри інфекційних хвороб Харківської медичної академії післядипломної освіти; e-mail: infection@med. edu.ua

ORCID: https://orcid.org/0000-0003-2548-2467

Копча Василь Степанович - д. мед. н., професор кафедри інфекційних хвороб з епідеміологією, шкірними і венеричними хворобами Тернопільського національного медичного університету імені І.Я. Горбачевського; e-mail: kopcha@ukr.net

ORCID: https://orcid.org/0000-0001-9499-3733

\section{Information about the authors:}

Maly V.P. - MD, Professor, Head of the Infectious Diseases Department, Kharkiv Medical Academy of Postgraduate Education; e-mail: infection@med.edu.ua

ORCID: https://orcid.org/0000-0003-2548-2467

Kopcha V.S. - MD, Professor of the Infectious Diseases and Epidemiology, Skin and Venereal Diseases Department, I. Horbachevsky Ternopil National Medical University; e-mail: kopcha@ukr.net

ORCID: https://orcid.org/0000-0001-9499-3733

Конфрлікт інтересів: немає.

Authors have no conflict of interest to declare.

Отримано 20.08.2021 p. 